\title{
EVALUASI SISTEM INFORMASI KESEHATAN PUSKESMAS KOTA MATSUM DI MEDAN MENGGUNAKAN PENDEKATAN INSTRUMEN HEALTH METRICS NETWORK
}

\author{
Putra Apriadi Siregar; Luthfiah Mawar; Wan Rizky Chairunnisa; Maulida Rezkiah; Dinda \\ Wisdayanti; Ananda Nurul Hidayah; Rivai Diski Purba \\ Fakultas Kesehatan Masyarakat, Universitas Islam Negeri Sumatera Utara, Medan
}

Email : siregar.putra56@gmail.com

\begin{abstract}
Track Record Article

Diterima : 29 Maret 2019 Dipublikasi: 25 Juni 2019

\section{Abstract}

The implementation of a Health Information System (HIS) will produce an overview of the development of health service status in a health facility. This description can be seen by carrying out HIS evaluation activities. The HIS evaluation seeks to improve and strengthen the health available at the puskesmas, the results of these efforts are expected to be an important step to improve the quality of public health services. This study aims to determine the HIS description in Matsum City Health Center. The study was conducted by evaluating the HIS performance at the Puskesmas. The study was conducted at the City Matsum Health Center Medan, North Sumatra in July 2018. The subjects in this study were the Head of the Sub-Section of the Administration of the City of Matsum Health Center which was taken based on purposive sampling. The data used in the form of primary data taken by conducting direct interviews and observation. Check the validity of the data using the triangulation method. The HIS City Health Center Matsum performance evaluation was conducted using a version of $H M N$ version 4.0 by assessing various components of HIS. The results of evalution that have been conducted at the city Health Center in Matsum, from the six HIS components according to the HMN instrument, none of the components were included in the "not adequate" category with the highedst score on the Dissemination and Use Components while the lowest score was in the Data Management Component. The conclusion of this study is that the HMN-based Health Information System at Matsum City Health Center has been running quite well but still needs to be improved especially regarding data processing.
\end{abstract}

Keywords: Evaluation of HIS, Approach, Health Metrics Network, City Health Center

Abstrak
Penyelenggaraan Sistem Informasi Kesehatan (SIK) akan menghasilkan gambaran
mengenai perkembangan status pelayanan kesehatan yang ada pada suatu fasilitas
kesehatan. Gambaran tersebut dapat diketahui dengan melakukan kegiatan
evaluasi SIK. Evaluasi SIK berupaya sebagai peningkatan dan pemantapan
kesehatan yang ada di puskesmas, hasil dari upaya tersebut diharapkan sebagai
langkah penting untuk meningkatkan mutu kualitas pelayanan kesehatan
masyarakat. Penelitian ini bertujuan untuk mengetahui gambaran SIK di Puskesmas
Kota Matsum. Penelitian dilakukan dengan mengevaluasi kinerja SIK di Puskesmas.
Penelitian dilakukan di Puskesmas Kota Matsum Medan, Sumatera Utara pada Juli
2018. Subjek pada penelitian ini yaitu Kepala Subbagian Tata Usaha Puskesmas
Kota Matsum yang diambil berdasarkan Purposive sampling. Data yang digunakan
berupa data primer yang diambil dengan melakukan wawancara langsung dan
obsevasi. Pengecekan validitas data menggunakan triangulasi metode. Evaluasi
kinerja SIK Puskesmas Kota Matsum dilakukan menggunakan pendeketan
instrumen Health Metrics Network (HMN) version 4.0 dengan menilai berbagai
komponen SIK. Hasil evaluasi yang telah dilakukan di Puskesmas Kota Matsum, dari
enam komponen SIK menurut instrumen HMN, seluruh komponen tidak ada yang
masuk dalam kategori "tidak memadai" dengan skor tertinggi pada Komponen
Diseminasi dan penggunaan sedangkan skor terendah pada Komponen Manajemen


Data. Kesimpulan dari penelitian ini adalah Sistem Informasi Kesehatan berbasis HMN pada Puskesmas Kota Matsum sudah berjalan cukup bagus tetapi masih perlu ditingkatkan lagi khususnya mengenai pengolahan data.

Kata Kunci: Evaluasi SIK, Pendekatan , Health Metrics Network, Puskesmas

\section{Pendahuluan}

Kementerian Kesehatan RI berupaya untuk mencapai tujuan pembangunan kesehatan Indonesia dengan membuat Sistem Informasi Kesehatan Nasional, program ini dilakukan demi tersedianya informasi yang bermanfaat untuk mendukung pengambilan keputusan dalam melaksanakan program Kesehatan. Sistem informasi kesehatan nasional terdapat 7 komponen yang saling terhubung dan saling terikat, yaitu: sumber data manual, sumber data komputerisasi, sistem informasi dinas kesehatan, sistem informasi pemangku kepentingan, bank data kesehatan nasional, pengguna data oleh kementerian kesehatan dan pengguna data. Masalah klasik yang terjadi saat ini adalah pengelolaan data dan informasi belum terkoordinasi dengan baik, terdapat banyaknya tumpang tindih kegiatan dan pengelolaan data, dimana masing-masing unit mengumpulkan data sendiri dengan instrumen yang berbeda di berbagai tingkat. Selain itu pengumpulan data belum dilakukan secara efisien dan kadang data yang dikumpulkan redundant, bahkan tidak diperlukan. Ini diakibatkan oleh SIK yang terfragmentasi. SIK yang saat ini dibangun hanya untuk satu unit dan untuk satu fungsi yang ada di bagian tersebut, namun belum dapat digunakan untuk dimanfaatkan unit lain untuk fungsi yang lain (Hartono, 2002).

Hasil penelitian Nyamtema (2010) memperlihatkan bahwa lemahnya pengumpulan data kesehatan dan kurangnya informasi pengambilan keputusan di fasilitas pelayanan kesehatan menjadi faktor sulitnya pengembangan SIK di Tanzania . Hasil penelitian Hartono (2007) memperlihatkan bahwa dari enam komponen dan standar SIK, lima diantaranya dinilai "ada tapi tidak adekuat" yaitu sumber daya (47\%), indikator (61\%), sumber data (51\%), kualitas data (55\%), dan diseminasi dan penggunaan. informasi (57\%). Sementara ada satu komponen yang dinilai "tidak adekuat sama sekali", yaitu komponen manajemen data (35\%).
Perkembangan kesehatan disuatu negara sangat perlu diperhatikan. Namun pada kenyataan SistemInformasi Kesehatan yang merupakan salah satu tujuan pembangunan kesehatan di Indonesia masih belum memberikan hasil yang akurat, lengkap dan tepat waktu. Hal itu dikarenakan banyaknya tantangan yang dihadapi dalam menjalani SIK terutama pada pihak penyelenggara SIK yang masih kurang paham dengan SIK sendiri sehingga SIK belum dilaksanakan secara efisien dan menghasilkan data yang kurang berkualitas (Kemenkes RI, 2012). Sistem Informasi Kesehatan perlu diselenggarakan di seluruh tatanan upaya kesehatan guna mendukung penyelenggaraan pembangunan kesehatan (Permenkes RI, 2015).

Evaluasi pelaksanaan peta jalan SIK dilakukan pada tahun 2011 sampai dengan 2014 kemudian ditemukannya masalah untuk mencapai target yang diinginkan salah satunya terbatasnya pembiayaan adalah yang menjadi penghambat pelaksanaan kegiatan. Permasalahan yang muncul dalam menjalankan SIK mengenai kemampuan sumber daya dalam mengelola SIK yang masih terbatas, data dan informasi serta indikator belum dijalankan dengan baik, kemampuan sumber data dalam menyediakan data maupun informasi masih lemah, belum efektif dan efisiennya dalam kegiatan pengumpulan, pengolahan dan analisis serta informasi, dana dalam mendukung sumber daya khususnya pada bagian teknologi informasi dan komunikasi serta sarana prasarana, peningkatan dan pengembangan mutu SIK masih belum optimal, dan juga data dan informasi yang dihasilkan dari SIK belum digunakan sepenuhnya dalam pembangunan kesehatan nasional (Permenkes RI, 2015). Tidak berhasilnya program tersebut harus bisa menjadi acuan bagi pembagunan kesehatan di Indonesia bahwa SIK di Indonesia masih sangat perlu ditingkatakan. Sistem Informasi Kesehatan memiliki kedudukan yang strategis dalam sistem kesehatan dan manajamen 
kesehatan. SIK tidak dapat berdiri sendiri melainkan merupakan bagian yang tidak terpisahkan dari sistem kesehatan. Oleh karena itu, perlu diselenggarakannya SIK di setiap upaya kesehatan sesuai dengan jenjang administrasi pemerintahan. SIK di tingkat pusat merupakan bagian dari sistem kesehatan nasional, di tingkat provinsi merupakan bagian dari sistem kesehatan provinsi, dan di tingkat kabupaten/kota merupakan bagian dari sistem kesehatan kabupaten/kota (Permenkes RI, 2005).

Menurut WHO (1990) bahwa evaluasi merupakan suatu cara yang sistematis dalam mempelajari berdasarkan pengalaman dan mempergunakan palajaran yang telah dipelajari untuk memerbaiki kegiatan yang sedang berjalan serta melakukan perencanaan yang lebih baik dengan seleksi yang seksama untuk kegiatan selanjutnya. Kemenkes RI (2012) menyatakan bahwa pada tahun 2007, Pusat Data dan Informasi telah melakukan evaluasi SIK dengan menggunakan perangkat Health Metricts Network-World Health Organization (HMN-WHO). Health Metrics Network (HMN) ini merupakan assessment tool yang digunakan untuk menilai atau mengevaluasi sistem informasi kesehatan disuatu daerah atau negara. Evaluasi ini meliputi 6 komponen utama SIK yaitu sumber daya (meliputi pengelolaan dan sumber daya), indikator, sumber data, manajemen data (pengumpulan; pengolahan dan analisis data), kualitas data, diseminasi dan penggunaan data.

Berdasarkan penelitian yang dilakukan oleh Tirzanny, dkk (2013) mengenai permasalahan SIK di puskesmas kabupaten Minahasa Tenggara menunjukkan bahwa pengelolaan/pelaksanaan SIK belum terlaksana secara online, semuanya masih manual, yaitu masih menggunakan pencatatan pada buku register dan formulir-formulir khusus. Tidak ada pedoman dalam penyelenggaraannya. Sebagian besar puskesmas belum ada sumber daya manusia (SDM) di bidang SIK dan tidak ada pelatihan khusus. Tidak ada dana khusus untuk SIK serta sarana dan prasarana untuk computer belum lengkap/tidak merata. SIK Nasional dibangun dari himpunan atau jaringan SIK Provinsi. Begitu juga SIK Provinsi dibangun dari himpunan atau jaringan SIK Kabupaten/Kota. Adanya mekanisme saling hubung antar subsistem informasi dengan berbagai cara yang sesuai, akan menghasilkan SIK yang terintegrasi. Dengan demikian, SIK dikembangkan harus selaras dengan tatanan tersebut guna meningkatkan penguatan SIK di Indonesia.

Hasil penilaian sistem informasi kesehatan dengan menggunakan perangkat penilaian dari Health Metric Network (HMN) yang dilakukan pada tahun 2012 menunjukkan bahwa keenam komponen penyelenggaraan sistem informasi kesehatan belum cukup memadai, terutama untuk komponen manajemen data masih kurang. Namun demikian, jika dibandingkan dengan tahun 2007 secara umum terlihat adanya perbaikan terutama pada komponen sumber daya.

Berdasarkan Permenkes tahun 2015 bahwa hasil penilaian SIK menggunakan penilaian berupa instrumen pendekatan HMN pada tahun 2012 memberikan hasil yaitu dari keenam komponen penyelenggaraan SIK belum cukup memadai, salah satu pada komponen manajemen data yang masih kurang memadai, tetapi bila dibandingkan dengan hasil penilaian SIK pada tahun 2007, secara umum sudah memiliki peningkatan khususnya pada komponene sumber daya (Permenkes, 2015).

Menurut Kemenkes RI, (2012), pada tahun 2007 Pusat data dan Informasi telah melakukan evaluasi mengenai SIK dengan menggunakan instrumen pedoman HMN dan mendapatkan hasil dari keenam komponen SIK yaitu "ada namun tidak adequate". Namun hasil tersebut lebih baik bila dibandingkan dengan pelaksaan SIK pada tahun 2004 yang dilaksanakan oleh sebagian rumah sakit maupun puskesmas tanpa menggunakan pedoman atau panduan pelakasanaan.

Berdasarkan hasil penelitian yang dilakukan Wahyuni, dkk (2018) evaluasi SIK pada Puskesmas Kampung Baru yang terletak di Kota Medan memperoleh hasil dari keenam komponen yang di evaluasi menurut instrumen HMN, seluruh komponen berupa Komponen Sumber Daya SIK, Komponen Indikator, Komponen Sumber Data, Komponen Manajemen Data, Komponen Produk Informasi, dan Komponen Diseminasi dan Penggunaan masuk dalam kategori "sangat memadai" dengan skor tertinggi pada Komponen Indikator (100\%) dan skor terendah pada 
Komponen Manajemen Data (87\%). Secara keseluruhan gambaran kinerja SIK di Puskesmas Kp. Baru Kota Medan Provinsi Sumatera Utara "sangat memadai".

Hasil penelitian Damayati (2015) memperlihatkan kelengkapan data masih kurang padahal anggaran untuk penerapan ePuskesmas sudah tersedia dengan cukup. Hal ini dapat dilihat dari masing-masing puskesmas memiliki anggaran untuk operasional sistem informasi manajemen kesehatan berbasis web yang dianggarkan secara rutin. Anggaran tersebut digunakan untuk pemeliharaan hardware (perangkat keras), software (perangkat lunak) dan biaya untuk koneksi internet.

Pengembangan SIK menurut HMN membutuhkan 6 (enam) komponen yang saling berinteraksi antara satu sama lainnya sehingga menghasilkan informasi yang lebih baik untuk kesehatan yang lebih baik pula. 6 komponen SIK tersebut. (WHO, 2008). Penetapkan 6 komponen yang merupakan standar penilaian Sistem Informasi Kesehatan antara lain sumber daya SIK, indikator, sumber data, manajemen data, produk informasi dan pemanfaatan dan diseminasi. Kemudian berdasarkan situasi dan masalah-masalah yang dihadapi SIK di Indonesia, maka disusunlah 7 komponen SIK di Indonesia anatara lain pengelola SIK, indikator, sumber data, manajemen data, sumber daya SIK, pengembangan SIK, pemanfaatan dan diseminasi (Kemenkes RI, 2012).

Ayat yang harus menjadi rujukan penilaian kinerja ada dalam Al-Quran pada surat AtTaubah ayat 105 Yang artinya Dan, katakanlah: "Bekerjalah kamu, maka, Allah dan Rasul-Nya, serta orang-orang mukmin akan melihat pekerjaanmu itu, dan kamu akan dikembalikan kepada Allah Yang Mengetahui akan yang gaib dan yang nyata, lalu diberitakan-Nya kepadamu apa yang telah kamu kerjakan". Dalam ayat ini tertulis "Bekerjalah kamu, maka, Allah dan Rasul-Nya, serta orang-orang mukmin akan melihat pekerjaanmu itu". Kita sebagai orang yang mukmin di perintahkan untuk melakukan pekerjaan dan mengevaluasi setiap pekerjaan yang telah dikerjakan. Sama halnya dengan Sistem Informasi Kegiatan (SIK). Perlunya diadakan evaluasi kesehatan guna memperbaiki kekurangan untuk mencapai tujuan yang telah di tetapkan sebelumnya.
Berdasarkan uraian diatas maka perlunya diadakan evaluasi dalam sistem informasi kesehatan di puskesmas sebagai upaya peningkatan dan pemantapan kesehatan yang ada di puskesmas. Hasil dari upaya tersebut diharapkan sebagai langkah penting untuk meningkatkan mutu kualitas pelayanan kesehatan masyarakat. Hal ini menjadi alasan untuk kemudian dilakukannya evaluasi terhadap sistem informasi kesehatan di Puskesmas Kota Matsum.

\section{Metode}

Jenis penelitian yang digunakan dalam penelitian ini yaitu penelitian dengan pendekatan deskriptif kualitatif. Penelitian ini dilakukan pada tahun 2018 di Puskesmas Kota Matsum Kota Medan.

Informan terpilih dalam penelitian ini yaitu Kepala Puskesmas Kota Matsum, Kepala Sub.Bagian Tata Usaha Puskesmas Kota Matsum dan melakukan observasi dengan menggunakan lembar observasi berdasarkan pedoman Health Metric Network (HMN) serta melakukan telaah dokumen. Data sekunder dalam penelitian ini didapatkan dari dokumen dan studi kepustakaan yang berkaitan dengan evaluasi terhadap sistem informasi kesehatan di Puskesmas Kota Matsum.

Penelitian ini dilakukan dengan cara mengevaluasi kinerja SIK berdasarkan pedoman wawancara dan observasi yaitu pedoman Health Metric Network (HMN). pengolahan data, peneliti menggunakan pengolahan manual. Hasil data yang terkumpul kemudian diolah dengan cara reduksi, display, analisis dan pengambilan keputusan. Penelitian ini dilakukan pada Puskesmas Kota Matsum Provinsi Sumatera Utara yang dimulai pada tanggal 11 Juli 2018.

Pengolahan data, peneliti menggunakan pengolahan manual. Hasil data yang terkumpul kemudian diolah dengan cara reduksi, display, analisis dan pengambilan keputusan. Dalam penelitian kualitatif ini pengecekan keabsahan menggunakan Triangulasi metode, yaitu dilakukan dengan cara membandingkan informasi atau data dengan cara yang berbeda. Sebagaimana dikenal, dalam penelitian kualitatif peneliti menggunakan metode wawancara dengan menggunakan pedoman wawancara dan obervasi dengan menggunakan 
lembar observasi serta melakukan telaah dokumen.

\section{Hasil}

Penelitian ini dilakukan di Puskesmas Kota Maksum dengan melakukan wawancara mendalam, melakukan observasi menggunakan lembar observasi dan melakukan telaah dokumen untuk mengevaluasi Sistem Informasi Kesehatan Puskesmas Kota Maksum Kota Medan.

Berdasrkan grafik 1.1 diketahui bahwa diketahui bahwa Desiminasi dan Penggunaan Informasi (Dissemination \& use) merupakan data tertinggi dan termasuk kategori sangat memadai (Highly adequate) sedangkan data manajemen (Data management) merupakan data paling rendah dan termasuk dalam kategori memadai (Adequate). Pada diagram diatas maka dapat dilihat bahwa terdapat tiga yang telah mencapai highly adequate yaitu Indicators, Information Product, dan Dissemination \& use sedangkan lainnya baru mencapai kategori memadai.

Berdasarkan Tabel 1. diketahui bahwa hasil evaluasi komponen SIK di Puskesmas Kota Maksum untukkomponen sumber daya termasuk dalam kategori memadai (72\%) dengan nilai Policy and Planning kategori sangat memadai (86\%) HIS institutions, human resources and financing kategori memadai (56\%) HIS Infrastructure kategori sangat memadai (93\%). Evaluasi komponen Indikator termasuk dalam kategori sangat memadai (80\%). Komponen Sumber Data secara keseluruhan termasuk dalam kategori memadai $(58 \%)$ dengan hasil sensus dalam kategori memadai (50\%) vital statistik kategori tidak memadai (14\%) population-based surveys kategori memadai (56\%) health\& disease record kategori memadai $(71 \%)$ health service records kategori sangat memadai $(79 \%)$ dan resource record kategori sangat memadai (77\%). Pada komponen selanjutnya yaitu manejemen data termasuk dalam kategori memadai (53\%). Evaluasi yang dilakukan terhadap produk informasi menunjukkan hasil dalam kategori sangat memadai (78\%). Untuk komponen Pemanfaatan dan Diseminasi secara keseluruhan termasuk dalam kategori sangat memadai (90\%) dengan hasil penilaian terhadap Analysis and use of information dalam kategori sangat memadai (100\%) Information use for policy and advocating dikategori memadai (67\%) Information Use For Planing and Priority Setting dikategori sangat memadai (100\%) Information use for Resource Allocation termasuk kadalam kategori sangat memadai (83\%) dan Information use for implemenrtation and action dikategori sangat memadai (89\%).

\section{Pembahasan}

SIK merupakan seperangkat tatanan yang melibatkan ataupun menggunakan data, informasi, indikator, prosedur, perangkat dan teknologi serta sumber daya manusia yang memiliki kaitan satu sama lain dan dikelola dengan tujuan dapat mengarahkan tindakan atau keputusan yang berguna dalam mencapai tujuan pembangunan kesehatan. Salah satu standar penilaian SIK dapat dilakukan menggunakan pendekatan instrumen HMN yang ditetapkan oleh WHO berdasarkan kesepakatan global. Penelitian ini dilakukan di Puskesmas Kp. Baru Provinsi Sumatera dengan melakukan survei kebutuhan SIK dilapangan berdasarkan pedoman wawancara kepada petugas yang memiliki pengetahuan dan kemampuan dalam menjawab dengan menggunakan pendekatan instrumen Health Metrics Network (HMN).

Setelah dilakukannya penelitian di Puskesmas Kota Matsum di Sumatera Utara tahun 2018 dan dilakukannya observasi langsung ke lokasi penelitian maka penelitian ini menggunakan satu informan yang memiliki informasi yang sangat banyak dan terpercaya mengenai Sistem Informasi Kesehatan di Puskesmas Kota Matsum dan melakukan observasi terhadap dokumen dan kelengkapan alat-alat SIK yang ada di Puskesmas Kota Matsum.

Hasil penilaian terhadap Sumber Daya SIK adalah termasuk dalam kategori "memadai (adequate)", yaitu dengan persentase sebesar $72 \%$. Hal ini dikarenakan di dalam komponen Sumber Daya ini, sub komponen Kebijakan dan Perencanaan memiliki persentase (86\%) yang tergolong sangat memadai, ini disebabkan karena puskesmas telah menjalankan SIK berdasarkan UU terbaru dan dijalankan secara penuh dan teratur. Pada sub komponen Institusi Pengelola, SDM dan Pembiayaan SIK memiliki persentase (56\%) yang tergolong memadai, ini disebabkan unit SIK telah berfungsi pada Puskesmas Kota Matsum tetapi 
masih terdapat kekurang pada sumber daya dan fasilitas SIK. Kemudian untuk ketersediaan Infrastruktur SIK sudah tersedia untuk keperluan dasar SIK yang bersumber dari Dinas Kesehatan yang memiliki persentase (93\%) tergolong sangat memadai. Sumber Daya Sistem Informasi Kesehatan pada Puskesmas Kota Matsum sudah sesuai dengan Peraturan Presiden Nomor 46 Tahun 2014 tentang SIK namun Puskesmas tersebut masih perlu melakukan peningkatan

terutama pada bagian sumber daya atau tenaga SIK yang harus memiliki pengalaman dibidangnya dan dapat bijak mengatasi masalah SIK dalam Puskesmas tersebut.

Hasil penilaian terhadap Indikator SIK adalah masuk dalam kategori "Sangat Memadai (Highly Adequate)", yaitu dengan persentase sebesar $80 \%$. Hal ini dikarenakan di dalam komponen indikator ini, pelaporan pada set minimum indikator bersifat reguler yang di laporkan secara teratur yaitu setahun sekali. Indikator inti minimum nasional telah diidentifikasi ke tingkat nasional dan subnasional yang mencakup semua kategori indikator kesehatan (faktor penentu kesehatan; masukan sistem kesehatan, keluaran dan hasil; dan status kesehatan). Pemilihan dan penetapan indikator SIK di Puskesmas Kota Matsum sudah sesuai dengan ketentuan dalam PP Nomor 46 Tahun 2014 dan kerangka HMN.

Hasil penelitian Lestari (2016) menunjukkan bahwa hasil evaluasi terhadap 7 komponen SIK di Provinsi Jawa Tengah menunjukkan bahwa empat komponen berada dalam kategori "Ada tapi tidak Adekuat" yaitu komponen Pengelolaan SIK, Sumber Daya SIK, Sumber Data SIK dan Manajemen Data SIK. Sementara tiga komponen lainnya berada dalam kategori "Adekuat", yaitu komponen Indikator SIK, Produk Informasi SIK dan Diseminasi dan Penggunaan Informasi. Hasil penelitian Jakti (2016) memperlihatkan bahwa hasil penilaian SIJARIEMAS mengguanakn assesment tolls HMN menunjukkan skor pada sumber daya $84 \%$, indikator $33 \%$, sumber data $64 \%$, manajemen data $25 \%$, produk informasi $73 \%$ dan diseminasi dan penggunaan informasi $39 \%$.

Penilaian terhadap komponen Sumber data termasuk dalam kategori memadai
Dengan berpedoman pada Kuesioner HMN maka data yang didapat dari aspek Census, Vital statistics, Population-based surveys, Health \& disease records, dan Resource records rata-rata nilai adalah $58 \%$ sehingga sumber data pada Puskesmas Kota Matsum tergolong memadai (adequat) meskipun begitu masih diperlukan peningkatan dikarenakan penilaian masih rendah meskipung tergolong adequat. Ratarata aspek masih diperlukan pembenahan atau peningkatan terutama pada data vital satatstics dan data cencus karena masih ada tetapi tidak memadai (Present but not adequat). Data-data tersebut sebenarnya tidak diharapkan untuk sebuah layanan kesehatan milik negara sehingga masih diperlukan peningkatan yang signifikan pada masing-masih aspek untuk menjadi tempat pelayanan kesehatan yang sangan memadai.

Data manajemen memiliki nilai ratarata yaitu memadai (53\%). Meskipun memadai, data manajemen masih jauh untuk mencapai sangat memadai maka dari itu diperlukannya dorongan untuk meningkatakan layanan pada manajemen data terutama pada data sistem informasi kesehatan. Hal ini dikarenakan kurangnya pengumpulan data yang dikumpulkan dan disimpan didalam gudang penyimpanan pelaporan kesehatan. Apabila pengelolaan manajemen data bisa berjalan dengan baik maka akan menghasilkan informasi yang berguna dan lebih berarti bagi penerimanya yang menggambarkan suatu kejadian sehingga akan berguna untuk pengambilan keputusan. Pengumpulan data secara rutin umumnya dilakukan oleh petugas kesehatan. Komponen manajemen data SIK di Puskesmas Kota Matsum masih memadai. Hal ini dikarenakan pada puskesmas Kota Matsum kurang dalam melaksanakan prosedur yang dibuat mengenai manajemen data terkait pengumpulan data yang dikumpulkan dan disimpan didalam gudang penyimpanan pelaporan kesehatan yang berisi informasi seperti laporan indikator kesehatan, cara pengumpulan data kesehatan, waktu pengumpulan data, teknik analisis data yang digunakan, dan demografi. Apabila manejemen data diolah dengan baik maka maka akan mengahasilkan data dan informasi yang berkualitas. penduduk. Akan tetapi pengumpulan data secara rutin juga dapat dilakukan oleh masyarakat (kader kesehatan). 
Bentuk lain dari pengumpulan data secara rutin adalah registrasi vital. Adapun pengumpulan data secara non-rutin umumnya dilakukan melalui survei, sensus, evaluasi cepat (kuantitatif atau kualitatif), dan studi-studi khusus/penelitian. Intervensi kesehatan tidak efektif dan tidak tepat sasaran tanpa informasi dan data yang akurat dan tepat waktu. Pengumpulan data ersebut apabila dilakukan secara teratur dan sesuai dengan pedoman dapat embuat manejemen data pada Puskesmas Kota Matsum bisa termasuk dalam kategori Sangat Memadai.

Hasil penelitian Damayati (2015) menunjukkan bahwa kelengkapan data di puskesmas percontohan e-Puskesmas dikategorikan kurang, hal ini tidak terlepas dari jumlah operator di puskesmas perontohan e -Puskesmas dikategorikan kurang sehingga berdampak kepada kelengkapan data. Seluruh kepala puskesmas di puskesmas percontohan e-Puskesmas mendukung penerapan ePuskesmas dan masing-masing puskesmas memiliki anggaran untuk biaya operasional penerapan e- Puskesmas yang dianggarkan secara rutin.

Hasil penilaian pada komponen Produk Informasi SIK di Puskesmas Kota Matsum memiliki rata-rata (78\%) tergolong sangat memadai. Pada komponen ini mengambil data dari data mortalitas, morbiditas dan faktor resiko. Data mortalitas dibawah 5 tahun Puskesmas Kota Matsum dengan kriteria penilaian kualitas yaitu metode pengumpulan data didapatkan dengan cara melihat riwayat kelahiran dan sistem pendaftara sampel, ketepatan waktu tidak lebih dari 2 tahun, periodisitas telah terjadi lebih dari 3 kali dalam 10 tahun terakhir, konsisten data yang dimiliki tidak memiliki perbedaan besar selama 10 tahun terakhir, data kematian sudah lebih dari 90\% dilaporkan, data-data sudah disusun berdasarkan karakteristik dan metode penyesuaiannya terjadi secara transparan dan mapan. Pada mortalitas Ibu sama dengan usia dibawah 5 tahun.Morbiditas Pravalensi HIV, Indikator Status Kesehatan Cakupan Vaksin Campak, Evaluasi Tenaga Kesehatan yang Profesional dan Kelengkapan Administrasi Kesehatan, Cakupan Tingkat Keberhasilan Pengobatan TB, Pengeluaran Anggaran Dana Kesehatan oleh Pemerintah dan Lembaga Terkait, Pengeluaran Anggaran Pribadi untuk
Kebutuhan Pelayanan Kesehatan, Jumlah Tenaga Kesehatan yang Bekerja di Fasilitas, dan Pravalensi Merokok sudah sangat memadai karena sudah sesuai dengan peraturan pemerintah. Data produk informasi memiliki nilai rata-rata yaitu $78 \%$ (highly adequate). Hal ini cukup bagus untuk sebuah layanan kesehatan negara karena dapat dipahami bahwa pengolahan data menjadi informasi untuk perencanaan dan pengambilan keputusan sudah cukup relevan. Hasil ini dapat membuat pandangan bahwa informasi memiliki atau memegang peranan penting terhadap sebuah organisasi.

Tujuan akhir dari pengembangan sistem informasi adalah penyajian data dan informasi untuk mendukung kegiatan pengambilam keputusan dan penetapan kebijakan. Setiap pengelolaan SIK, baik itu yang masih bersifat manual maupun komputerisasi wajib melakukan pelaporan sesuai dengan standar dataset minimal yang telah ditetapkan oleh Kementrian Kesehatan. Hasil penilaian pada komponen Diseminasi dan Penggunaan SIK di Puskesmas Kota Matsummemiliki ratarata $(90 \%)$ tergolong sangat memadai. Hal ini dikarenakan di dalam komponen Diseminasi dan Penggunaan SIK ini, sub komponen Analisis dan Penggunaan Informasi (100\%) yang tergolong sangat memadai dikarenakan oleh pentingnya informasi yang telah diterapkan pada puskemas seperti terdapatnya informasi-informasi yang jelas dan relevan sehingga mempermudah sistem informasi, Kebijakan dan Advokasi (67\%) tergolong memadai dikarenakan sistem pelaporan sudah bagus hanya saja belum terpublikasi ke seluruh masyarakat hanya kepada dinas kesehatan saja, Perencanaan dan Pengaturan Prioritas $(100 \%)$ tergolong sangat memadai dikarenakan perencanaan dan proses alokasi sumber daya di Puskesmas Kota Matsum berguna untukmerencanakan pengembangan terpadu tahunan, Alokasi Sumber Daya (83\%) tergolong sangat memadai karena telah didukung oleh adanya dukungan-dukungan, dan Implementasi dan Tindakan (89\%) tergolong sangat memadai dikarenakan informasi-informasi kesehatan sudah diberikan kepada para manajer puskesmas dan informsi tersebut digunakan untuk propil puskesmas dan mengantisipasi resiko dengan memperhatikan faktor-faktor resiko yang ada. 
Hal ini menunjukkaan bahwa penyebaran dan penggunaan data pada Puskesmas Kota Matsum sudah sangat memadai tetapi ada salah satu aspek yang masih adequate dan jauh untuk tergolong kepada sangat memadai (highly adequate) yaitu aspek information us for policy and advocacy yang masih $67 \%$ (adequate) sehingga masih diperlukan peningkatan pada pelaksanaan kebijakan beserta advokasinya.

Puskesmas Kota maksum memiliki komponen SIK dengan rata-rata memadai hal ini dapat menunjukkan bahwa SIK pada Puskesmas Kota Matsum sudah berjalalan. Apabila pada setiap masing-masing komponen ditingkatkan khususnya pada bagian kinerja pelaksanaan SIK akan membuat data-data yang didapatkan dapat diolah menjadi informasi dan berguna dan dapat mewujudkan sistem informasi kesehatan yang mampu mendukung proses pembangunan kesehatan dalam menuju masyarakat sehat yang mandiri. Semakin baiknya kualitas dari sistem informasi kesehatan pada suatu puskesmas akan menggambarkan derajat kesehatan masyarakat hal ini dikarenakan perkembangan kesehatan masyarakat dapat diukur ataupun dipantau perkembangannya sehingga lebih mudah dalam melakukan penanganan dan peningkatan kesehatan pada masyarakat. Pengumpulan data-data yang didapatkan apa bila dikumpulkan dan dilaporkan secara tepat waktu pada bank data akan membuat keadaan kesehatan masyarakat akan dapat diperhatikan secara optimal sehingga apabila terjadi hal yang tidak diinginkan seperti KLB/Wabah dapat diketahui penyebabnyanya dan bagaimana cara pengendalian penyakit tersebut dengan menggunakan data-data yang telah dikumpul dalam bentuk informasi yang terkini sehingga tidak diperlukannya penyelidikan yang dialkukan dari awal. Hal itu membuat proses penanganan kasus penyakit berjalan secara efisien dan efektif.

Evaluasi SIK yang dilakukan oleh Lestari, dkk (2016) dalam penelitiannya tentang Evaluasi Sistem Informasi Kesehatan di Provinsi Jawa Tengah Dalam Rangka Penguatan Sistem Informasi Kesehatan Nasional diperoleh hasil bahwa secara keseluruhan evaluasi pada masing masing 7 komponen SIK yaitu anatara lain pengelola SIK, indikator, sumber data, manajemen data, sumber daya SIK, pengembangan SIK, pemanfaatan dan diseminasi di Provinsi Jawa Tengah berada dalam kategori "memadai". Pada empat komponen yaitu komponen pengelolaan, komponen sumber daya, komponen sumber data dan komponen manajemen data berada dalam kategori "tersedia tapi tidak memadai". Sedangkan tiga komponen lainnya seperti komponen indikator, komponen produk informasi dan komponen diseminasi dan penggunaan informasi berada dalam kategori "memadai" (Lestari, dkk., 2016).

Pelaksanaan SIK pada puskesmas lebih dilaksanakan dengan melakukan kerja sama dengan lintas sektor hal ini dikarenakan data yang digunakan merupakan data yang bersumber dari survei maupun sensus serta keterlibatan lintas sektor yang memiliki data terkait kesehatan lingkungan, iklim, cuaca, data kesehatan terkait pariwisata, kegiatan lalu lintas kendaraan/transportasi, ketenagakerjaan, terkait masalah sosial, hukum dan lain-lain. Hal itu akan membantu petugas SIK dalam mengumpulkan data-data terkait kesehatan karena mendapatkan data atau informasi dari sumber yang langsung menangani atau terjun langsung ke masalahmasalah kesehatan yang muncul pada sektor diluar sektor kesehatan.

Pelaksanaan evaluasi terkait kinerja pelaksanaan SIK pada Puskesmas sangat perlu dilakukan secara rutin hal ini dikarenakan data-data yang didapatkan dalam sistem informasi kesehatan ini sangat memberikan gambaran perkembangan ataupun kondisi kesehatan pada masyarakat. Sering sekali ditemukannya kelemahan pelaksanaan SIK di komponen sumber daya, dapat disimpulkan bahwa pelatihan pelaksanaan SIK kepada pelaksana atau penanggung jawab SIK harus secara rutin diberikan dan petugas pelaksana harus mengkhususkan diri dalam pelaksanaan SIK. Kerja ganda atau mengambil dua tanggung jawab sering dilakukan oleh petugas SIK sehingga dalam menjalankan tanggung jawabnya dalam menjalankan SIK memiliki kendala waktu dan tidak optimal menjalankannya.

Untuk mencapai sangat memadai peneliti menyarankan kepada Puskesmas Kota Matsum untuk komponen sumber daya untuk ditingkatkan lagi dalam sumber daya manusia 
yang mengelolah SIK dan sumber daya mampu menggunakan peralatan SIK dengan semaksimal mungkin, dan diharapkan agar peralatan yang digunakan untuk pelaksanaan SIK dapat dipenuhi sehingga SIK dapat berjalan sesuai dengan pedoman pelaksanaan. Komponen Sumber Data bisa mencapai sangat memadai dengan cara melaksanakan sensus kepada masyarakat secara rutin dan melakukan pencatatan serta pelaporan data secara teratur sehingga data-data bisa secara tepat waktu dandata data kesehatan bisa diterima oleh masyarakat. Komponen manejemen data masih sangat perlu ditingkatkan, meskipun telah mencapai kategori memadai tetapi masih sangat jauh untuk mencapai kategori sangat memadai. Hal ini berarti masih perlunya parbaikan dalam pengelohan pada komponen manajem data dengan cara melakukan pengumpulan datadata dengan teratur dan memiliki tempat khusus sebagai penyimpanan data-data kesehatan sehingga data-data kesehatan mudah disediakan setiap kali dibutuhkan datadata tersebut.

\section{Kesimpulan dan Saran}

Kesimpulan dari penelitian adalah Keberhasilan pelaksanaan suatu sistem bergantung pada sumber daya yang mendukung sistem tersebut. Sumber Daya SIK di Puskesmas Kota Matsum termasuk dalam kategori "Adequate" (75\%). Berdasarkan hasil evaluasi diketahui bahwa komponen Sumber Data SIK di Puskesmas Kota Matsum "Adequate" (58\%).Secara keseluruhan hasil evaluasi manajemen data SIK di Puskesmas Kota Matsum masuk dalam kategori "Adequate" (53\%). Hasil penilaian terhadap produk informasi SIK di Puskesmas kota Matsum masuk ke dalam kategori "Adequate" (71\%). Hasil evaluasi terhadap desiminasi dan penggunaan informasi pada SIK di Puskesmas Kota Matsum "Highly adequate" (90\%). Hal ini menunjukkan sistem informasi kesehatan berbasis HMN pada Puskesmas Kota Matsum sudah berjalan cukup bagus tetapi masih perlu meningkatkan mutu kualitas pelayanan kesehatan masyarakat khususnya dalam pengolahan data.

Saran yang dapat diberikan adalah kepada Petugas puskesmas yang memiliki tanggung jawab terhadap pelaksanaan SIK lebih profesional dalam melaksanakan pekerjaannya dan ditingkatkan kinerja serta kualitas pelayanan kesehatan pada puskesmas karena telah memengang amanah yang penting - Kepada pemerintah diharapkan lebih mengoptimalkan Sistem Informasi Kesehatan pada puskesmas dengan mengerjakan petugas SIK yang sesuai dengan peraturan perundangundangan dan berkopeten dan diharapkan juga bisa melengkapi fasilitas untuk mendukung pelaksanaan SIK. Kepada sesama peneliti diharapkan lebih sering melakukan penelitian mengenai evaluasi Puskesmas sehingga Puskesmas yang merupakan pelayanan kesehatan primer dapat bekerja lebih optimal.

Evaluasi yang telah dilakukan terhadap kinerja SIK di puskesmas kota matsum berdasarkan pedoman penilaian menggunakan instrumen HMN terha dap 6 (enam)komponen terdapat 3 (tiga) komponen yang telah mencapai kategori sangat memadai sedangkan 3 (tiga) komponen lainnya masih mencapai kategori memadai. Untuk mencapai sangat memadai peneliti menyarankan kepada puskesmas kota matsum untuk komponen sumber daya untuk ditingkatkan lagi dalam sumber daya manusia yang mengelolah SIK dan sumber daya mampu menggunakan peralatan SIK dengan semaksimal mungkin, dan diharapkan agar peralatan yang digunakan untuk pelaksanaan SIK dapat dipenuhi sehingga SIK dapat berjalan sesuai dengan pedoman pelaksanaan. Komponen Sumber Data bisa mencapai sangat memadai dengan cara melaksanakan sensus kepada masyarakat secara rutin dan melakukan pencatatan serta pelaporan data secara teratur sehingga datadata bisa secara tepat waktu dandata data kesehatan bisa diterima oleh masyarakat. Komponen manejemen data masih sangat perlu ditingkatkan, meskipun telah mencapai kategori memadai tetapi masih sangat jauh untuk mencapai kategori sangat memadai. Hal ini berarti masih perlunya parbaikan dalam pengelohan pada komponen manajem data dengan cara melakukan pengumpulan datadata dengan teratur dan memiliki tempat khusus sebagai penyimpanan data-data kesehatan sehingga data-data kesehatan mudah disediakan setiap kali dibutuhkan datadata tersebut.

Peran serta dinas kesehatan dalam meningkatkan kinerja SIK pada Puskesmas 
dapat dilakukan dengan memberikan pelatihan-pelatihan sumber daya pelaksana SIK sehingga sumber daya menjadi terampil dalam menjalankan tugasnya. Sumber daya juga harus dikhususkan sehingga sumber daya SIK tidak menjalani kerja ganda dengan kegiatan puskesmas lainnya. Dinas juga bisa memenuhi kebutuhan untuk pelaksanaan SIK seperti dari segi sarana prasarana, peralatan seperti alat mengirimkan laporan secara online agar pencatatan dan pelaporan data-data bisa tepat waktu. Terdapat 3 (tiga) komponen yang masih belum mencapai kategori sangat memadai seperti komponen sumber daya, dinas kesehatan bisa memfasilitasi sumber daya SIK dalam menjalankan sistem informasi kesehatan pada Puskesmas Kota Matsum begitu juga dengan sumber data data dan manejemen data di Puskesmas Kota Matsum.

\section{Daftar Pustaka}

Damayati, Dwi Santy. 2015. Gambaran Penerapan Sistem Informasi Manajemen Kesehatan Berbasis WEB di Puskesmas Kota Makassar Tahun 2015. Al-Sihah : Public Health Science Journa Volume 7, Nomor 2, Juli-Desember 2015; 19-202.

Depkes RI. (2001) Sistem Informasi Kesehatan. Jakarta : Depkes RI.

Hartono B, Bambang S, Tjahjoso D. 2007. Indonesia Health Information System Review and Assessment.

HMN. (2013). Pedoman HMN. http://www.who.int/helthmetrics/en/

Jakti, Uray Bilchairi. 2016. Evaluasi Sistem Informasi Jejaring Rujukan MaternalNeonatal (SIJARIEMAS) di Kabupaten Tegal Dengan Pendekatan Model Health Metrics Network (HMN). Wawasan Kesehatan Vol 3, No 1 Juli 2016; 109-118.

J. Meleong, Lexy. (2009). Metodologi Penelitian Kualitatif: Bandung : Remaja Rosdakarya.

Kemenkes RI. (2011) Pedoman Sistem Informasi Kesehatan. Jakarta: Kementrian kesehatan.
Kemenkes RI. (2012). Sistem Informasi Kesehatan Tahun 2011-2014. (Jakarta:Bakti Husada).

Lestari, dkk. (2016). Evaluasi Sistem Informasi Kesehatan di Provinsi Jawa Tengah. Semarang: Universitas Diponegoro.

M, Tirzany V, dkk. Analisis Pelaksanaan Sistem Informasi Kesehatan diPuskesmas Kabupaten Minahasa Tenggara.

Ningsih, dkk. (2016). Health Metrics Network (HMN) System.

Nyamtema, AS. 2010. Bridging the gaps in the Health Management Information System in the Context of a Changing Health Sector. BMC Med Inform Decis Mak. 2010 Jan;10;36.

Permenkes. (2015) Peta Jalan Sistem Informasi Kesehatan Tahun 2015-2019.

Rahardjo, Mudjia. (2012). Triangulasi dalam penelitian kualitatif.

Raharyanti, Fenny. dkk. (2014). Pelaksanaan BPJS Kesehatan Kota Bogor Tahun 2014 dalam Rangka Meningkatkan Derajat Kesehatan Masyarakat.

SIMKES UGM. (2008). Komponen HMN. https://www.kompasiana.com/asnawio $\mathrm{k} /$ sistem-informasikesehatan 54fd1a38a33311111d50f878. com.

Sukmadinata, N.S. (2009). Metode Penelitian Pendidikan: Bandung (ID): PT.Remaja Rosda Karya.

Syahdrajat, Tantur.(2015). Panduan Menulis Tugas Akhir Kedokteran \& Kesehatan: Jakarta: Kencana.

Utami, Tri Niswati. dkk. (2015). Perspektif Kesehatan Masyarakat Teori dan Aplikasi: Yogyakarta: Deepublish.

WHO. (2006). Health Metrics NetworkStrengthening Country Health Information: Assessment andMonitoring Tool. World Health Organization 
Grafik 1

Hasil Evaluasi 6 Komponen SIK di Puskesmas Kota Matsum Tahun 2018

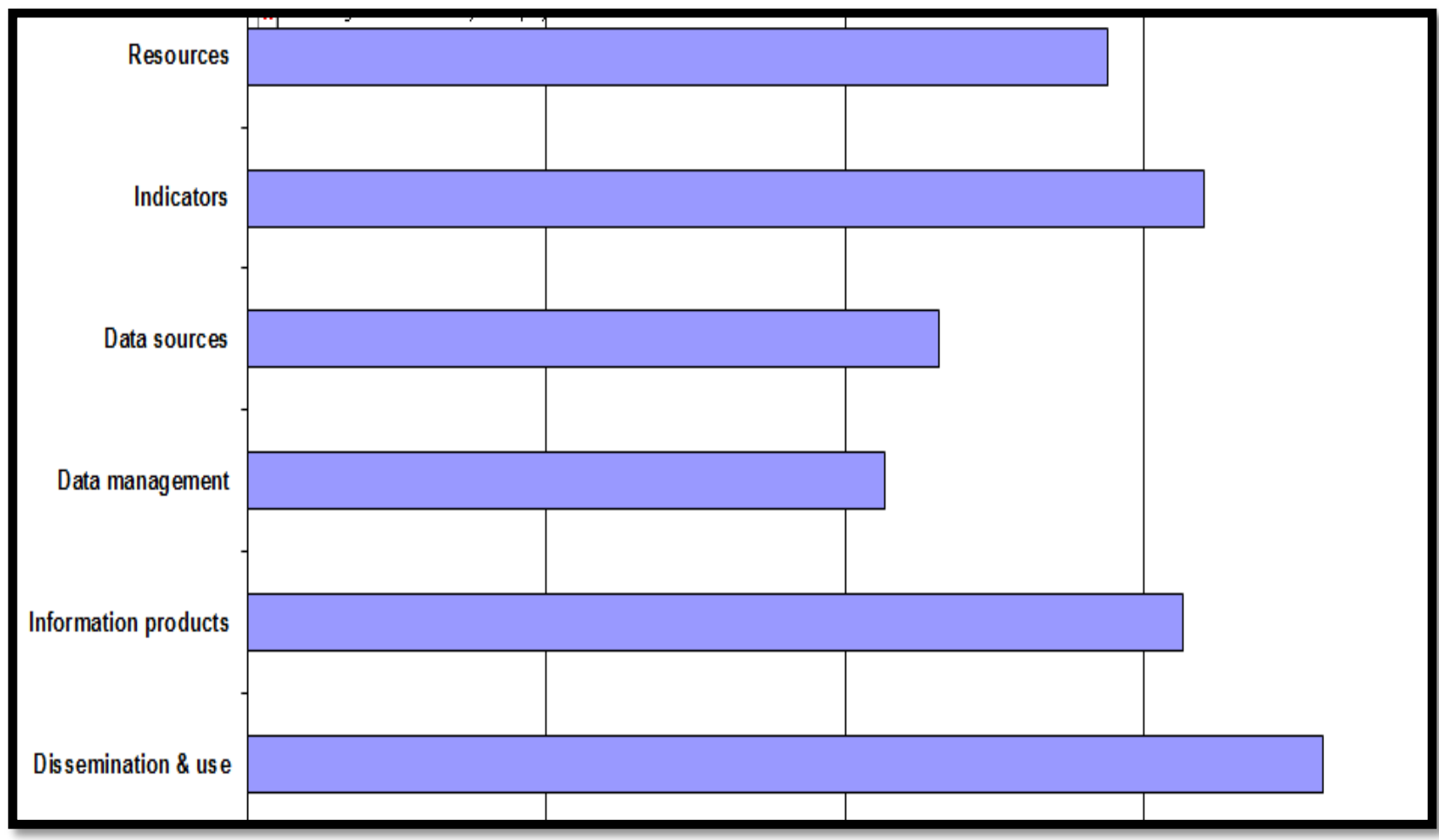

Tabel 1

Hasil Evaluasi 6 Komponen SIK di Puskesmas Kota Matsum Tahun 2018

\begin{tabular}{|c|c|c|c|c|c|}
\hline NO & KATEGORI & $\begin{array}{c}\text { TOTAL } \\
\text { SKOR } \\
\text { MAKSIMUM }\end{array}$ & $\begin{array}{l}\text { SKOR } \\
\text { RATA- } \\
\text { RATA }\end{array}$ & $\%$ & KATEGORI \\
\hline 1. & $\begin{array}{ll}\text { Sumber Daya } \\
\\
\text { - } \quad \text { Kebijakan dan Perencanaan } \\
\text { - } & \text { Institusi, Sumber Daya Manusia, } \\
& \text { dan Pembiayaan SIK } \\
- & \text { Infrastuktur SIK }\end{array}$ & $\begin{array}{l}75 \\
21 \\
39 \\
15\end{array}$ & $\begin{array}{l}\mathbf{5 4 , 0} \\
18,0 \\
22.0 \\
14,0\end{array}$ & $\begin{array}{l}72 \% \\
86 \% \\
56 \% \\
93 \%\end{array}$ & $\begin{array}{l}\text { Memadai } \\
\text { Sangat Memadai } \\
\text { Memadai } \\
\text { Sangat Memadai }\end{array}$ \\
\hline 2 & Indikator & 15 & 12,00 & $80 \%$ & Sangat Memadai \\
\hline 3 & \begin{aligned} & \multicolumn{2}{l}{ Sumber Data } \\
& - Sensus \\
& - Statistik Vital \\
& - Survei Berbasis Populasi \\
& - Pencatatan Kesehatan dan \\
& Penyakit \\
& - Pencatatan \\
& Kesehatan Pelayanan \\
& - Pencatatan Sumber Daya \end{aligned} & & & $\begin{array}{l}\mathbf{5 8 \%} \\
50 \% \\
14 \% \\
56 \% \\
71 \% \\
79 \% \\
77 \% \\
\end{array}$ & $\begin{array}{c}\text { Memadai } \\
\text { Memadai } \\
\text { Tidak Memadai } \\
\text { Memadai } \\
\text { Memadai } \\
\text { Sangat Memadai } \\
\text { Sangat Memadai }\end{array}$ \\
\hline 4 & Manejemen Data & 15 & 8,0 & $53 \%$ & Memadai \\
\hline 5 & Produk Informasi & 168 & 132,0 & $78 \%$ & Sangat Memadai \\
\hline
\end{tabular}




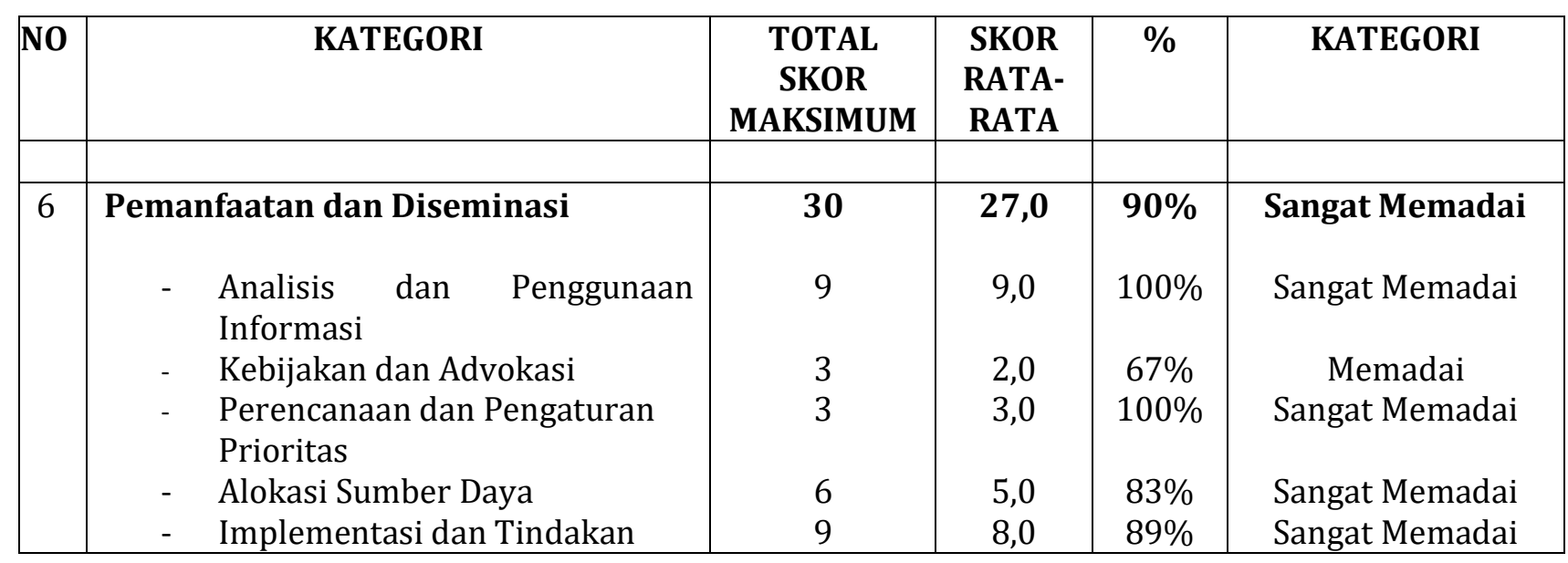

